\title{
On the phase formation of sputtered hafnium oxide and oxynitride films
}

Kostas Sarakinos, D. Music, S. Mraz, M. To Baben, K. Jiang, F. Nahif, A. Braun, C. Zilkens,

S. Konstantinidis, F. Renaux, D. Cossement, F. Munnik and J. M. Schneider

\section{Post Print}

N.B.: When citing this work, cite the original article.

Original Publication:

Kostas Sarakinos, D. Music, S. Mraz, M. To Baben, K. Jiang, F. Nahif, A. Braun, C. Zilkens, S. Konstantinidis, F. Renaux, D. Cossement, F. Munnik and J. M. Schneider, On the phase formation of sputtered hafnium oxide and oxynitride films, 2010, Journal of Applied Physics, (108), 1, 014904.

http://dx.doi.org/10.1063/1.3437646

Copyright: American Institute of Physics (AIP) http://www.aip.org/

Postprint available at: Linköping University Electronic Press http://urn.kb.se/resolve?urn=urn:nbn:se:liu:diva-71476 


\title{
On the phase formation of sputtered hafnium oxide and oxynitride films
}

\author{
K. Sarakinos, ${ }^{1, a)}$ D. Music, ${ }^{1}$ S. Mráz, ${ }^{1}$ M. to Baben, ${ }^{1}$ K. Jiang, ${ }^{1}$ F. Nahif, ${ }^{1}$ A. Braun, ${ }^{1}$ \\ C. Zilkens, ${ }^{1}$ S. Konstantinidis, ${ }^{2}$ F. Renaux ${ }^{3}$ D. Cossement, ${ }^{3}$ F. Munnik, ${ }^{4}$ and \\ J. M. Schneider ${ }^{1}$ \\ ${ }_{1}^{1}$ Materials Chemistry, RWTH Aachen University, Kopernikusstr. 16, D-52056 Aachen, Germany \\ ${ }^{2}$ Laboratoire de Chimie Inorganique et Analytique, Université de Mons, Avenue Copernic 1, \\ 7000 Mons, Belgium \\ ${ }^{3}$ Materia Nova Research Center, Avenue Copernic 1, 7000 Mons, Belgium \\ ${ }^{4}$ Forschungszentrum Dresden Rossendorf, P.O. Box 510119, D-01314 Dresden, Germany
}

(Received 18 March 2010; accepted 2 May 2010; published online 8 July 2010)

\begin{abstract}
Hafnium oxynitride films are deposited from a Hf target employing direct current magnetron sputtering in an $\mathrm{Ar}-\mathrm{O}_{2}-\mathrm{N}_{2}$ atmosphere. It is shown that the presence of $\mathrm{N}_{2}$ allows for the stabilization of the transition zone between the metallic and the compound sputtering mode enabling deposition of films at well defined conditions of target coverage by varying the $\mathrm{O}_{2}$ partial pressure. Plasma analysis reveals that this experimental strategy facilitates control over the flux of the $\mathrm{O}^{-}$ions which are generated on the oxidized target surface and accelerated by the negative target potential toward the growing film. An arrangement that enables film growth without $\mathrm{O}^{-}$ion bombardment is also implemented. Moreover, stabilization of the transition sputtering zone and control of the $\mathrm{O}^{-}$ion flux without $\mathrm{N}_{2}$ addition is achieved employing high power pulsed magnetron sputtering. Structural characterization of the deposited films unambiguously proves that the phase formation of hafnium oxide and hafnium oxynitride films with the crystal structure of $\mathrm{HfO}_{2}$ is independent from the $\mathrm{O}^{-}$ bombardment conditions. Experimental and theoretical data indicate that the presence of vacancies and/or the substitution of $\mathrm{O}$ by $\mathrm{N}$ atoms in the nonmetal sublattice favor the formation of the cubic and/or the tetragonal $\mathrm{HfO}_{2}$ crystal structure at the expense of the monoclinic $\mathrm{HfO}_{2}$ one. (C) 2010 American Institute of Physics. [doi:10.1063/1.3437646]
\end{abstract}

\section{INTRODUCTION}

Hafnium dioxide $\left(\mathrm{HfO}_{2}\right)$ exists in three low pressure crystalline phases; (i) the monoclinic $\mathrm{HfO}_{2}\left(\mathrm{~m}-\mathrm{HfO}_{2}\right.$, space group $\mathrm{P} 21 / \mathrm{c}$ ) up to a temperature of $\sim 1900 \mathrm{~K}$, (ii) the tetragonal $\mathrm{HfO}_{2}\left(\mathrm{t}-\mathrm{HfO}_{2}\right.$, space group $\left.\mathrm{P} 42 / \mathrm{nmc}\right)$ in the temperature range $1900-2500 \mathrm{~K}$, and (iii) the cubic $\mathrm{HfO}_{2}$ (c- $\mathrm{HfO}_{2}$, space group $\mathrm{Fm} 3 \mathrm{~m}$ ) at temperatures above $2500 \mathrm{~K}$. In addition, at high pressures the formation of the orthorhombic phase $\left(\mathrm{o}-\mathrm{HfO}_{2}\right.$, space group $\left.\mathrm{Pbca}\right)$ is observed. ${ }^{2,3}$ First principle calculations by Zhao and Vinderbilt ${ }^{4}$ have suggested that among the low pressure phases $\mathrm{c}-\mathrm{HfO}_{2}$ and $\mathrm{t}-\mathrm{HfO}_{2}$ exhibit dielectric constants $(\kappa)$ of $\sim 29$ and $\sim 70$, respectively, which are much larger than that of the $\mathrm{m}-\mathrm{HfO}_{2}$ $(\kappa \sim 16-18)$. Therefore, $\mathrm{HfO}_{2}$ films with the cubic and/or the tetragonal crystal structure are widely used as high-k dielectric layers in field effect transistors. ${ }^{5}$ In film form, $\mathrm{HfO}_{2}$ can be deposited by a variety of techniques, including atomic layer deposition, ${ }^{6}$ electron beam evaporation, ${ }^{7}$ radio frequency, ${ }^{8-12}$ direct current, $^{13-15}$ pulsed $^{16}$ and high pressure $^{17}$ magnetron sputtering, molecular beam epitaxy, ${ }^{18}$ and pulse laser deposition. ${ }^{2,3}$ With all these techniques, growth at room temperature commonly results in the formation of the $\mathrm{m}-\mathrm{HfO}_{2}$ phase $\mathrm{e}^{10,12,16,17,19,20}$ or amorphous films. ${ }^{2,3,5-8,13,15}$ Therefore, considerable research effort has been focused on the room temperature growth of the t- and the $\mathrm{c}-\mathrm{HfO}_{2}$ phases. A number of studies have shown that the

\footnotetext{
${ }^{\text {a) }}$ Author to whom correspondence should be addressed. Electronic mail: sarakinos@mch.rwth-aachen.de.
}

alloying of the metal sublattice of $\mathrm{HfO}_{2}$ by $\mathrm{Y}$ (Ref. 19) and Fe (Ref. 21) could stabilize the cubic phase at room temperature, while the incorporation of Si facilitated the room temperature deposition of $\mathrm{t}-\mathrm{HfO}_{2}$. 6,10

Recently, Severin et al. ${ }^{22}$ reported the growth of cubic $\mathrm{ZrO}_{2}$ films ${ }^{23}\left(\mathrm{ZrO}_{2}\right.$ is isostructural with $\left.\mathrm{HfO}_{2}\right)$ by reactive direct current magnetron sputtering (dcMS) from a $\mathrm{Zr}$ target in an $\mathrm{Ar}-\mathrm{O}_{2}-\mathrm{N}_{2}$ gas atmosphere. These films were $\mathrm{O}$ deficient (with respect to the nominal $\mathrm{ZrO}_{2}$ stoichiometry) and contained up to 10 at. $\% \mathrm{~N}^{22}$ It was also reported ${ }^{24}$ that the presence of $\mathrm{N}_{2}$ in the sputtering atmosphere enabled the stabilization of the transition zone between the metallic and the compound (oxidic) sputtering mode. It is known ${ }^{25}$ that during the reactive deposition of metal oxides the transition sputtering zone is commonly unstable and it is, in general, characterized by a lower degree of oxidation (coverage) of the target surface, as compared to the compound sputtering mode. Tominaga et al. ${ }^{26}$ and Mráz and Schneider ${ }^{27,28}$ demonstrated that on a covered (oxidized) target surface negatively charged $\mathrm{O}^{-}$ions can be formed and accelerated by the negative target potential impinging onto the growing film with energies of several hundreds of electron volt. Ngaruiya et $a{ }^{29}{ }^{29}$ postulated and Mráz and Schneider $^{27}$ showed that these ions have implications for the structure evolution of transition metal oxides. Severin et al. ${ }^{22}$ suggested that the lower target coverage in the transition zone allows for a suppression of the $\mathrm{O}^{-}$flux toward the growing film and speculated that the latter is the reason for the growth of films with the $\mathrm{c}-\mathrm{ZrO}_{2}$ crystal structure. However, no experimental evi- 
dence for this suggestion has been presented so far. Furthermore, the effect of chemical composition of the films on the stability of the various phases was not considered.

In the present study, we deposit films from a $\mathrm{Hf}$ target using dcMS in a reactive $\mathrm{Ar}-\mathrm{O}_{2}-\mathrm{N}_{2}$ ambient to evaluate the viability of $\mathrm{N}_{2}$ addition for the stabilization of the transition zone during deposition of hafnium oxynitrides and the room temperature growth of films with the crystal structure of c- $\mathrm{HfO}_{2}$. In addition, we implement an experimental arrangement ${ }^{30}$ that allows for the elimination of high energy $\mathrm{O}^{-}$ions impinging on the substrate. This approach enables us to shed a light on the role of the $\mathrm{O}^{-}$ion bombardment on the phase formation. To evaluate the significance of possible $\mathrm{N}$ incorporation and $\mathrm{O}$ deficiency, we compile a research strategy that allows for stabilization of the transition sputtering zone without $\mathrm{N}_{2}$ addition. The latter is facilitated by the use of high power pulsed magnetron sputtering (HPPMS). ${ }^{31}$ HPPMS is a newly developed ionized physical vapor deposition technique in which the power is applied to the target in unipolar pulses of low duty cycle $(<10 \%)$ and frequency $(<10 \mathrm{kHz}){ }^{31}$ This mode of operation leads to the generation of ultra dense plasmas with degrees of ionization of the sputtered material significantly larger than those obtained in conventional magnetron sputtering techniques (e.g., dcMS) and has been shown to result in the deposition of films with superior properties as compared to dcMS. ${ }^{32,33}$ Furthermore, it has been reported that HPPMS enables the stabilization of the transition zone during reactive deposition of oxides. ${ }^{34,35}$ Here, we employ this feature of HPPMS and deposit films using various $\mathrm{Ar}$ and $\mathrm{O}_{2}$ partial pressures. Parallel to the experimental studies, ab initio calculations based on the density functional theory (DFT) are performed to assess the effect of the nonmetal sublattice $(\mathrm{N}$ and $\mathrm{O})$ population on the stability of the various $\mathrm{HfO}_{2}$ phases.

\section{EXPERIMENTAL PROCEDURE}

The depositions of the hafnium oxide and oxynitride films were performed in a standard DN 100 CF-6 way cross (volume $0.011 \mathrm{~m}^{3}$ ) on $\mathrm{Si}(100)$ wafers without external substrate heating. The power was applied to a Hf target with a diameter of $90 \mathrm{~mm}$ and a purity of $99.9 \%$ by a MELEC pulsing unit ${ }^{36}$ fed by an ADL dc generator which was operating at a constant average current of $0.8 \mathrm{~A}$. This experimental arrangement allows for operation both in dcMS and in HPPMS modes. ${ }^{37}$ Prior to the plasma ignition, the vacuum chamber was pumped down to a base pressure of $\sim 10^{-4} \mathrm{~Pa}$. The experiments were performed in $\mathrm{Ar}-\mathrm{O}_{2}$ and $\mathrm{Ar}-\mathrm{O}_{2}-\mathrm{N}_{2}$ atmospheres employing dcMS and HPPMS. In the case of experiments carried out in $\mathrm{Ar}-\mathrm{N}_{2}-\mathrm{O}_{2}$ ambient the $\mathrm{N}_{2}$ partial pressure $\left(\mathrm{p}_{\mathrm{N}_{2}}\right)$ was held constant at $0.1 \mathrm{~Pa}$, while in all cases Ar and $\mathrm{O}_{2}$ partial pressures $\left(\mathrm{p}_{\mathrm{Ar}}\right.$ and $\mathrm{p}_{\mathrm{O}_{2}}$, respectively) were varied accordingly to maintain a constant total working pressure of $0.8 \mathrm{~Pa}$. It has to be mentioned here that all partial pressures reported in the current study refer to values measured with a capacitance gauge without the presence of plasma. The target-to-substrate distance was $100 \mathrm{~mm}$. Prior to the film deposition, target voltage $\left(\mathrm{V}_{\mathrm{T}}\right)-\mathrm{p}_{\mathrm{O}_{2}}$ curves were recorded to evaluate the stability of the process. For experi-

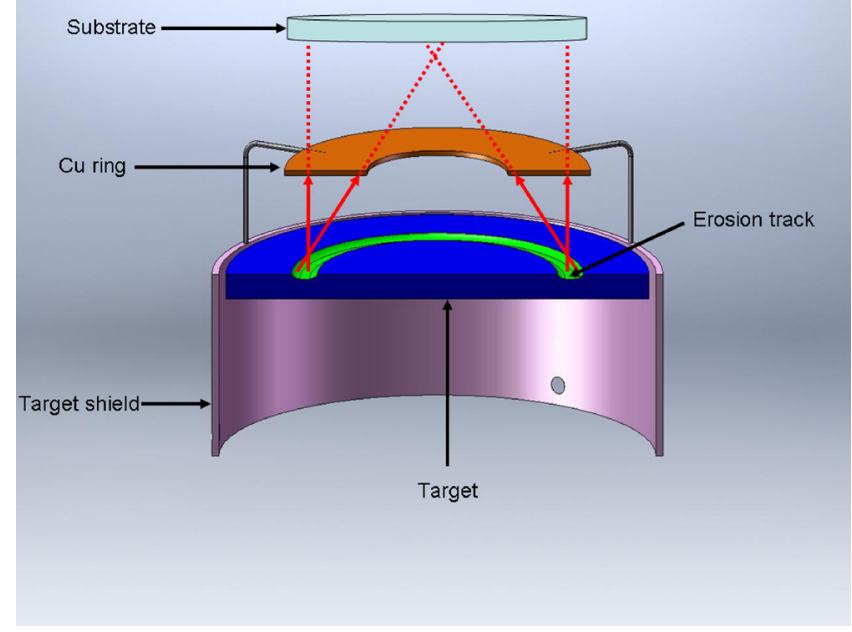

FIG. 1. (Color online) Schematic illustration of the experimental arrangement employed to suppress the $\mathrm{O}^{-}$bombardment. $\mathrm{A} \mathrm{Cu}$ ring placed above the target enables the blocking of the $\mathrm{O}^{-}$ions generated at the oxidized target surface (solid arrows). The dotted lines indicate the trajectories of the $\mathrm{O}^{-}$ions without the presence of the $\mathrm{Cu}$ ring.

ments performed in dcMS mode, $\mathrm{V}_{\mathrm{T}}$ was directly obtained from the readout of the dc generator. In the case of HPPMS process both target current and voltage are time dependent quantities which were measured using a LEM-205-S current and ELDITEST GE 8115 voltage transducer, respectively, and monitored in a Tektronik TDS 2014 digital oscilloscope. The measurements of the time dependent target voltage revealed nearly rectangular waveforms during the pulse ontime with $V_{T}$ values very similar to the readout of the dc generator. One set of films (Set 1) was deposited employing dcMS in a mixed $\mathrm{Ar}-\mathrm{O}_{2}-\mathrm{N}_{2}$ ambient and at an effective pumping speed of $23 \mathrm{ls}^{-1}$. The $\mathrm{V}_{\mathrm{T}}-\mathrm{p}_{\mathrm{O}_{2}}$ curves revealed that the process exhibited a stable and hysteresis free transition zone, as opposed to the processes without $\mathrm{N}_{2}$ addition. A second set of growth experiments (Set 2) was also performed in an $\mathrm{Ar}-\mathrm{O}_{2}-\mathrm{N}_{2}$ ambient and at a pumping speed of $23 \mathrm{ls}^{-1}$ but in this case a $\mathrm{Cu}$ ring with a thickness of $1 \mathrm{~mm}$ and inner and outer diameter of $30 \mathrm{~mm}$ and $65 \mathrm{~mm}$, respectively, was placed $20 \mathrm{~mm}$ above the target surface (Fig. 1). A similar arrangement was implemented by Severin ${ }^{30}$ during the reactive deposition of $\mathrm{ZnO}$ films. Based on changes in the texture of the deposited films it was inferred that the $\mathrm{Cu}$ ring serves as shield for the high energy $\mathrm{O}^{-}$ions generated at the target surface and prevent them from reaching the growing film ${ }^{30}$ (see Fig. 1). In a third set of experiments (Set 3) depositions were carried out employing HPPMS in an $\mathrm{Ar}-\mathrm{O}_{2}$ atmosphere (effective pumping speed $38 \mathrm{ls}^{-1}$ ). The power was applied to the target in unipolar pulses with an on-time $\left(\mathrm{t}_{\mathrm{on}}\right)$ of $50 \mu \mathrm{s}$ and an off-time $\left(\mathrm{t}_{\text {off }}\right)$ of $450 \mu \mathrm{s}$. The increase, with respect to the deposition Sets 1 and 2, of the pumping speed and the implementation of HPPMS allowed for a stable and hysteresis free transition zone without the addition of $\mathrm{N}_{2}$. It has to be pointed out here that the dcMS process at the same effective pumping speed of $38 \mathrm{ls}^{-1}$, exhibited a hysteresis and unstable transition zone. In all deposition sets the $\mathrm{p}_{\mathrm{Ar}} / \mathrm{p}_{\mathrm{O}_{2}}$ ratio in the sputtering atmosphere was varied in order to grow films at different target working points (i.e., target coverage) of the stable transition zone ranging from a 
metallic to a fully oxidized target aiming to tune the flux of $\mathrm{O}^{-}$ions toward the film, as well as the atomic composition of the films. ${ }^{22}$

The plasma chemistry and energetics at the various deposition conditions were studied by means of energyresolved mass spectrometry. A Pfeiffer Vacuum PPM 422 mass-energy analyzer equipped with a quadrupole mass spectrometer with an attached energy filter was employed to perform mass-to-charge measurements at constant energy, while ion energy distribution functions (IEDFs) were recorded at constant mass-to-charge ratios. The experiments were carried out in a DN $160 \mathrm{CF} / \mathrm{DN} 100 \mathrm{CF}$ reducing cross (volume $0.022 \mathrm{~m}^{3}$ ). The distance between the target and the grounded mass-energy analyzer sampling orifice was $70 \mathrm{~mm}$ and the orifice diameter was $100 \mu \mathrm{m}$. Measurements were performed for a target operating at a constant average current of $0.8 \mathrm{~A}$ both in dcMS and in HPPMS modes in $\mathrm{Ar}-\mathrm{O}_{2}-\mathrm{N}_{2}$ and $\mathrm{Ar}-\mathrm{O}_{2}$ atmosphere, respectively. The total working pressure was $0.8 \mathrm{~Pa}$ at an effective pumping speed of $841 \mathrm{~s}^{-1}$. Due to the differences in the geometry and the pumping speed between the plasma characterization and film deposition chambers the results of the plasma analysis serve for a qualitative comparison.

The effect of the deposition conditions on the chemical composition of the films was quantified by means of elastic recoil detection analysis (ERDA) using a $35 \mathrm{MeV} \mathrm{Cl}^{7+}$ ion beam. Moreover, the bonding properties of the films with various chemical compositions were investigated by $\mathrm{X}$-ray photoelectron spectroscopy (XPS). The XPS measurements were carried out in a VG ESCALB 220 iXL apparatus. Prior to the spectrum acquisition, the film surface was bombarded by $\mathrm{Ar}^{+}$ions with an energy of $3 \mathrm{keV}$ and a flux of $0.1 \mu \mathrm{A} / \mathrm{mm}^{2}$ in order to remove surface contaminants. For the measurements, a monochromatized x-ray beam (Al $K_{\alpha}$ radiation at $1486.6 \mathrm{eV}$ ) was utilized. The photoelectrons emitted from the surface were detected by a hemispherical multichannel analyzer. The phase composition of the films at the various deposition conditions was studied by means of $\mathrm{X}$-ray diffractometry (XRD). The XRD measurements were performed in a Bruker D8 General Area Detection Diffraction System equipped with a $\mathrm{Cu} K_{\alpha}$ source $(\lambda$ $=1.54056 \AA$ ) and a two-dimensional detector. The XRD patterns were recorded in grazing incidence geometry at an angle of incidence of $15^{\circ}$ and the angular position of the intensity maxima was compared to that of standard powder diffraction files for different $\mathrm{HfO}_{2}$ and $\mathrm{HfN}$ phases.

\section{THEORETICAL PROCEDURE}

The effect of the nonmetal $(\mathrm{O}$ and $\mathrm{N})$ sublattice configuration on the energetics of the various $\mathrm{HfO}_{2}$ phases was assessed by employing ab initio calculations based on the DFT. $^{38}$ The calculations were performed using the VASP software ${ }^{39,40}$ in conjunction with the generalized-gradient approximations projector augmented wave potentials. Reciprocal-space integration with a Monkhorst-Pack scheme, ${ }^{41}$ energy cutoff of $500 \mathrm{eV}$, and tetrahedron method with Blöchl corrections ${ }^{42}$ for the energy were used in the calculations. The total energy per atom $(E)$ was calculated for $\mathrm{Hf}_{16} \mathrm{O}_{32-x}$ and $\mathrm{Hf}_{16} \mathrm{O}_{32-x} \mathrm{~N}_{x}$ cells with the crystal structure of the monoclinic- $\left(\mathrm{m}-\mathrm{HfO}_{2}\right.$, space group $\left.\mathrm{P} 2{ }_{1} / \mathrm{c}\right)$, the tetragonal-(t- $\mathrm{HfO}_{2}$, space group $\left.\mathrm{P} 4_{2} / \mathrm{nmc}\right)$, and the cubic- $\mathrm{HfO}_{2}\left(\mathrm{c}-\mathrm{HfO}_{2}\right.$, space group $\left.\mathrm{Fm} 3 \mathrm{~m}\right)$. The $\mathrm{Hf}_{16} \mathrm{O}_{32-x}$ cells were constructed by removing $x \mathrm{O}$ atoms from the starting $\mathrm{Hf}_{16} \mathrm{O}_{32}$ configuration, while the $\mathrm{Hf}_{16} \mathrm{O}_{32-x} \mathrm{~N}_{x}$ cells were constructed by substituting $x \mathrm{O}$ by $x \mathrm{~N}$ atoms. The parameter $x$ was varied between 0 and 12 which is within the experimentally determined range of $\mathrm{O}$ vacancies and $\mathrm{N}$ incorporation (see Sec. IV B). The atomic positions in the nonmetal sublattice for $\mathrm{O}$ removal and/or $\mathrm{N}$ substitution were chosen using random numbers. For selected cells the nonmetal sublattice was constructed using the special quasirandom structures (SQS) implementation. ${ }^{43,44}$ The SQS implementation via the Warren-Cowley short-range order parameter ${ }^{45}$ is available within the locally self-consistent Green's function software package. ${ }^{45,46}$ The Warren-Cowley short-range order parameter for the nonmetal sublattice was within 0.03 for the first three coordination shells. The differences in the total energies between SQS cells and cells constructed by random numbers were in the order of $\sim 10 \mathrm{meV} /$ atom. These differences are small compared to the overall changes in the energy formation of the various $\mathrm{HfO}_{2}$ phases (see Sec. IV C). Thus, for the discussion of the phase stability the results from cells generated using random numbers are used. All cells were relaxed with respect to the ionic positions. The convergence criterion for the ionic and electronic relaxation was $1.0 \mathrm{meV}$ and $0.1 \mathrm{meV}$, respectively. Thereupon, the lattice parameters and the angles of the relaxed cells were varied in order to calculate the minimum total energy. For the calculations the following valence electrons configurations were utilized such as: $\operatorname{Hf}\left(5 d^{2} 6 s^{2}\right), \quad \mathrm{O}\left(2 s^{2} 2 p^{4}\right)$, and $\mathrm{N}\left(2 s^{2} 2 p^{3}\right)$. Selected cells were also calculated using a $\operatorname{Hf}\left(5 p^{6} 5 d^{2} 6 s^{2}\right)$ configuration. The results revealed that the differences in the equilibrium cell size between the two $\mathrm{Hf}$ valence electron configurations were less than $1 \%$. Therefore, the configuration with the smaller number of valence electrons $\left(5 d^{2} 6 s^{2}\right)$ was chosen in order to reduce the computational time. For the $\mathrm{t}-\mathrm{HfO}_{2}$ structure $2 \times 2 \times 2$ supercells with a k-points grid $4 \times 4 \times 4$ were utilized, while the c- and $\mathrm{m}-\mathrm{HfO}_{2}$ structures were described by $2 \times 2 \times 1$ supercells with a k-points grid of $4 \times 4 \times 8$.

The energy of formation $\left(E_{f}\right)$ for the various crystal structures was determined using the following expressions:

$$
\begin{aligned}
E_{f}\left(\mathrm{Hf}_{16} \mathrm{O}_{32-x}\right)= & E\left(\mathrm{Hf}_{16} \mathrm{O}_{32-x}\right)-\frac{16}{48-x} E(\mathrm{Hf}) \\
- & \frac{32-x}{48-x} E(\mathrm{O}) \\
E_{f}\left(\mathrm{Hf}_{16} \mathrm{O}_{32-x} \mathrm{~N}_{x}\right)= & E\left(\mathrm{Hf}_{16} \mathrm{O}_{32-x} \mathrm{~N}_{x}\right)-\frac{16}{48-x} E(\mathrm{Hf}) \\
& -\frac{32-x}{48-x} E(\mathrm{O})-\frac{x}{48-x} E(\mathrm{~N})
\end{aligned}
$$

The quantity $E(\mathrm{Hf})$ was calculated using a 16 atoms $2 \times 2$ $\times 2$ Hf supercell (space group $\mathrm{P}_{3} / \mathrm{mmc}$ ) utilizing a $5 \times 5$ $\times 5 \mathrm{k}$-points grid. For the calculation of the $\mathrm{O}$ and $\mathrm{N}$ ener- 


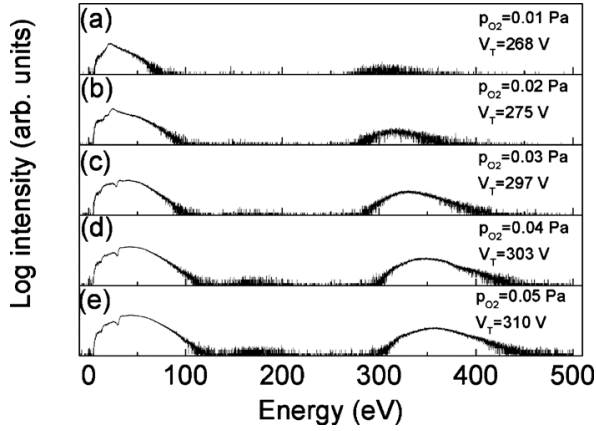

FIG. 2. IEDFs of $\mathrm{O}^{-}$ions recorded from an $\mathrm{Ar}-\mathrm{O}_{2}-\mathrm{N}_{2}$ dcMS discharge $\left(\mathrm{N}_{2}\right.$ partial pressure of $0.1 \mathrm{~Pa}$ ) at various $\mathrm{O}_{2}$ partial pressures $\left(\mathrm{p}_{\mathrm{O}_{2}}\right)$. The target voltage values $\left(\mathrm{V}_{\mathrm{T}}\right)$ at the corresponding conditions are also provided.

gies $(E(\mathrm{O})$ and $E(\mathrm{~N}))$ a $10 \times 10 \AA^{2}$ cube was constructed and the distance of two $\mathrm{O}$ and $\mathrm{N}$ atoms in the cube was varied in order to determine the minimum energy of this molecular configuration.

\section{RESULTS}

\section{A. Plasma characterization}

Mass-to-charge scans at constant energy were recorded at various discharge conditions for positive and negative ions. Among the various negatively charged species, such as $\mathrm{O}_{2}^{-}, \mathrm{OH}^{-}, \mathrm{O}^{-}$, and $\mathrm{O}^{-}$ions were found to be the dominant ones. The IEDFs of $\mathrm{O}^{-}$species measured from an Ar $-\mathrm{O}_{2}-\mathrm{N}_{2}$ dcMS discharge at $\mathrm{p}_{\mathrm{N}_{2}}=0.1 \mathrm{~Pa}$ and at $\mathrm{p}_{\mathrm{O}_{2}}$ values from 0.01 to $0.05 \mathrm{~Pa}$ are plotted in Figs. 2(a) $-2(\mathrm{e}) . \mathrm{V}_{\mathrm{T}}-\mathrm{pO}_{2}$ curves (not presented here) revealed that the chosen $\mathrm{p}_{\mathrm{O}_{2}}$ values correspond to target working points ranging from a nearly nonoxidized $\left(\mathrm{p}_{\mathrm{O}_{2}}=0.01 \mathrm{~Pa}\right)$ to an oxidized target $\left(\mathrm{p}_{\mathrm{O}_{2}}=0.05 \mathrm{~Pa}\right)$. It is seen that in all IEDFs two ion populations are present; a low energy population (energies up to $100 \mathrm{eV}$ ) and a high energy one (energies higher than 260 $\mathrm{eV})$. The signal that corresponds to both populations increases when $\mathrm{p}_{\mathrm{O}_{2}}$ is increased. The $\mathrm{O}^{-}$IEDF of the Ar $-\mathrm{N}_{2}-\mathrm{O}_{2}$ dcMS discharge at $\mathrm{p}_{\mathrm{O}_{2}}=0.05 \mathrm{~Pa}$ together with the IEDF from a discharge operating with a $\mathrm{Cu}$ ring above the target surface at otherwise identical conditions are plotted in Figs. 3(a) and 3(b), respectively. It can be seen that the implementation of the $\mathrm{Cu}$ ring does not significantly affect

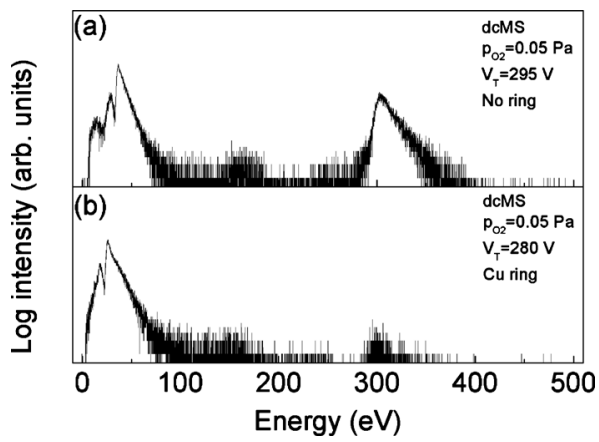

FIG. 3. IEDFs of $\mathrm{O}^{-}$ions recorded from an $\mathrm{Ar}-\mathrm{O}_{2}-\mathrm{N}_{2}$ dcMS discharge $\left(\mathrm{N}_{2}\right.$ partial pressure of $0.1 \mathrm{~Pa}$ ) (a) without and (b) with the $\mathrm{Cu}$ ring above the target (see Fig. 1) at otherwise identical conditions. The target voltage values $\left(\mathrm{V}_{\mathrm{T}}\right)$ at the corresponding conditions are also provided.

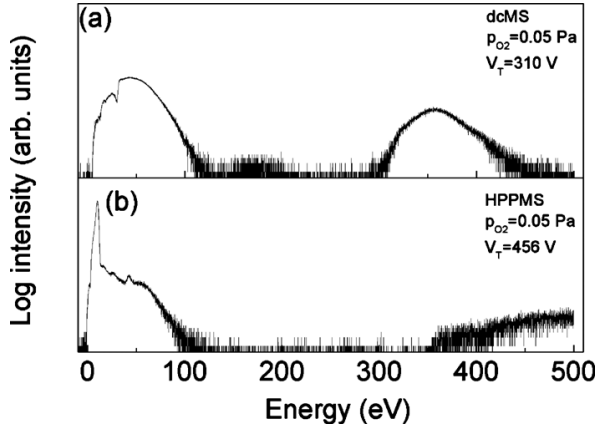

FIG. 4. IEDFs of $\mathrm{O}^{-}$ions recorded from (a) an $\mathrm{Ar}-\mathrm{O}_{2}-\mathrm{N}_{2}$ dcMS discharge $\left(\mathrm{N}_{2}\right.$ partial pressure of $0.1 \mathrm{~Pa}$ ) and (b) an $\mathrm{Ar}-\mathrm{O}_{2}$ HPPMS discharge (pulse on- and off-times 50 and $1450 \mu \mathrm{s}$, respectively) both at an $\mathrm{O}_{2}$ partial pressure of $0.05 \mathrm{~Pa}$. The target voltage values $\left(\mathrm{V}_{\mathrm{T}}\right)$ at the corresponding conditions are also provided.

the low energy $\mathrm{O}^{-}$ions, while the high-energy species are eliminated. Figures 4(a) and 4(b) show, respectively, the $\mathrm{O}^{-}$ IEDFs recorded from a dcMS and an HPPMS $\left(\mathrm{t}_{\mathrm{on}}=50 \mu \mathrm{s}\right.$ and $\mathrm{t}_{\text {off }}=1450 \mu \mathrm{s}$ ) discharge operating in an $\mathrm{Ar}-\mathrm{O}_{2}-\mathrm{N}_{2}$ ambient $\left(\mathrm{p}_{\mathrm{N}_{2}}=0.1 \mathrm{~Pa}\right.$ and $\left.\mathrm{p}_{\mathrm{O}_{2}}=0.05 \mathrm{~Pa}\right)$. Both discharges exhibit low-energy and high-energy populations of $\mathrm{O}^{-}$ions. The low-energy ions exhibit similar distributions with respect to the energy values. On the other hand, the onset of the high energy distribution for the HPPMS discharge is shifted to higher energies as compared to the dcMS discharge. Moreover, the dcMS IEDF exhibits in general a higher intensity than that of the HPPMS discharge. In all cases in Figs. 2-4 the target voltage $\left(\mathrm{V}_{\mathrm{T}}\right)$ values at the corresponding conditions are also provided.

\section{B. Film properties}

Films in deposition Set 1 (dcMS/ $\mathrm{Ar}-\mathrm{O}_{2}-\mathrm{N}_{2}$ ambient for $\mathrm{p}_{\mathrm{N}_{2}}=0.1 \mathrm{~Pa}$ ) were grown for $\mathrm{p}_{\mathrm{O}_{2}}$ values from 0.05 to $0.16 \mathrm{~Pa}$ which provided target working points ranging from a nonoxidized target to an oxidized one as revealed by the

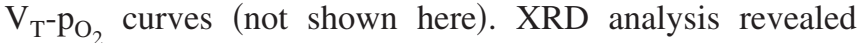
(XRD patterns not presented here) that the increase in the $\mathrm{O}_{2}$ partial pressure results in a transition from films with the crystal structure of the cubic $\mathrm{HfN}$ to films exhibiting the $\mathrm{HfO}_{2}$ crystal structure for $\mathrm{p}_{\mathrm{O}_{2}}$ values above $0.09 \mathrm{~Pa}$. The XRD pattern of a film grown at a $\mathrm{p}_{\mathrm{O}_{2}}$ value of $0.11 \mathrm{~Pa}$ is plotted in Fig. 5(a). This $\mathrm{p}_{\mathrm{O}_{2}}$ value allows for operation in the transition zone with a target voltage value $\left(\mathrm{V}_{\mathrm{T}}\right)$ of $332 \mathrm{~V}$. It is seen that the diffraction pattern exhibits intensity maxima (peaks) at angular positions which lie between those of the peaks in the published reference t- $\mathrm{HfO}_{2}$ (Ref. 47) and c- $\mathrm{HfO}_{2}$ (Refs. 48 and 49) patterns. As the $\mathrm{O}_{2}$ partial pressure is increased to $0.15 \mathrm{~Pa}$, operation in the oxidic mode with a $\mathrm{V}_{\mathrm{T}}$ value of $356 \mathrm{~V}$ is enabled. The diffraction pattern of a film grown at these conditions is shown in Fig. 5(b). This pattern is significantly different than the one in Fig. 5(a) indicating the formation of $\mathrm{m}-\mathrm{HfO}_{2}{ }^{50}$

ERDA measurements for the sample grown at $\mathrm{p}_{\mathrm{O}_{2}}$ $=0.11 \mathrm{~Pa}$ [data provided in Fig. 5(a)] revealed that the presence of $\mathrm{N}_{2}$ in the sputtering atmosphere results in $\mathrm{N}$ incorporation on the order of 22 at. \% in the film. The Hf and $\mathrm{O}$ concentrations are 42 at. \% and 36 at. \%, respectively. The 


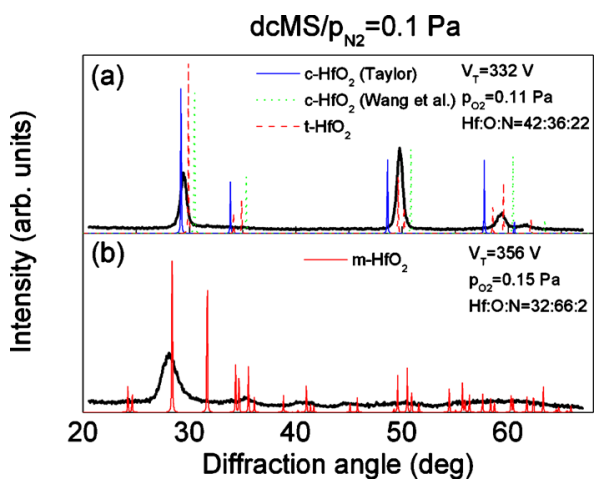

FIG. 5. (Color online) X-ray diffraction patterns of samples deposited by dcMS in an $\mathrm{Ar}-\mathrm{O}_{2}-\mathrm{N}_{2}$ atmosphere $\left(\mathrm{p}_{\mathrm{N}_{2}}=0.1 \mathrm{~Pa}\right)$ at $\mathrm{p}_{\mathrm{O}_{2}}$ values of (a) 0.11 and (b) $0.15 \mathrm{~Pa}$. The target voltage $\left(\mathrm{V}_{\mathrm{T}}\right)$ and chemical composition from the ERD analysis of the samples at the various deposition conditions are also provided. The vertical lines indicate the peak positions in the reference $\mathrm{HfO}_{2}$ patterns.

increase in the $\mathrm{O}_{2}$ partial pressure to $0.15 \mathrm{~Pa}$ leads to an increase in the $\mathrm{O}$ content in the film to 66 at. \%, while $\mathrm{N}$ and Hf concentrations decrease to 2 at. \% and 32 at. \%, respectively. The XPS measurement of the film grown at $\mathrm{p}_{\mathrm{O}_{2}}$ $=0.11 \mathrm{~Pa}$ is presented in Fig. 6(a). Here, the $\mathrm{O} 1 \mathrm{~s}$ peak is taken as reference and its binding energy is set to be equal to $530.4 \mathrm{eV}^{51}$ All other peaks are assigned with respect to the O 1 s peak, see, for example, the $\mathrm{N} 1 s$ peak at $395.9 \mathrm{eV}$ (Ref. 51) and the Hf $4 d_{3 / 2}$ peak at $212.9 \mathrm{eV}^{51}$ Apart from Hf, O, and N, no other species can be detected in the XPS spectrum. Figure $6(\mathrm{~b})$ presents the N $1 s$ peak. It is seen that this peak can be fitted to a single Gaussian function [red dashed line in Fig. 6(b)] indicating that it cannot be deconvoluted and, therefore, corresponds to a single bond-type.

The implementation of the $\mathrm{Cu}$ ring above the target surface (deposition Set 2) induced changes in reactive sputtering process. The $\mathrm{V}_{\mathrm{T}}-\mathrm{p}_{\mathrm{O}_{2}}$ curves showed that the transition to the oxidic sputtering mode occurred at lower $\mathrm{O}_{2}$ partial pressures as compared to the process in Set 1. The latter can be attributed to the change of the effective collecting area of the chamber ${ }^{25}$ caused by the introduction of the $\mathrm{Cu}$ ring. In addition, in Set 2 the $\mathrm{V}_{\mathrm{T}}$ values were approximately $60 \mathrm{~V}$ lower

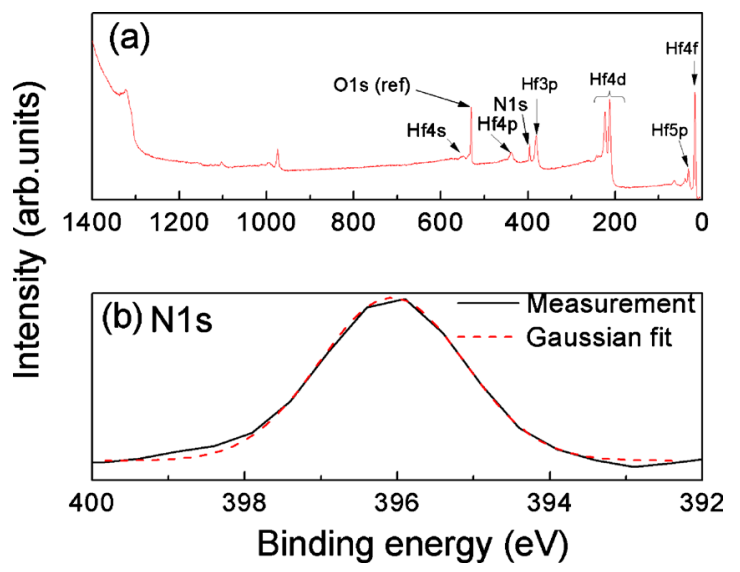

FIG. 6. (Color online) (a) XPS data of a film grown by dcMS in an Ar $-\mathrm{O}_{2}-\mathrm{N}_{2}$ atmosphere $\left(\mathrm{p}_{\mathrm{N}_{2}}=0.1 \mathrm{~Pa}\right.$ and $\left.\mathrm{p}_{\mathrm{O}_{2}}=0.11 \mathrm{~Pa}\right)$. (b) Zoom in the $\mathrm{N} 1 s$ peak at binding energy of $395.9 \mathrm{eV}$. The peak is fitted to a single Gaussian curve.

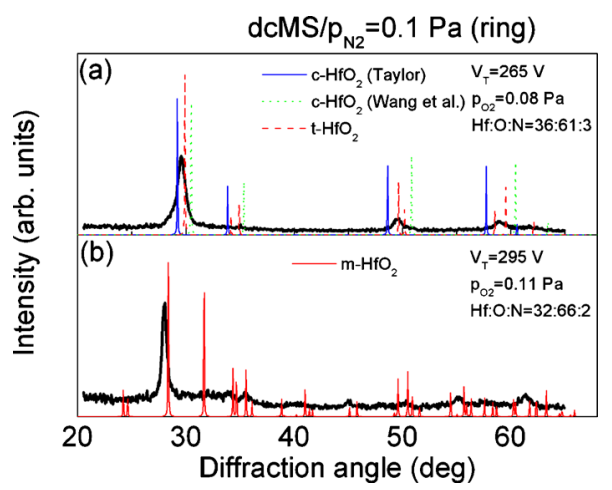

FIG. 7. (Color online) X-ray diffraction patterns of samples deposited by dcMS in an $\mathrm{Ar}-\mathrm{O}_{2}-\mathrm{N}_{2}$ atmosphere $\left(\mathrm{p}_{\mathrm{N}_{2}}=0.1 \mathrm{~Pa}\right)$ at $\mathrm{p}_{\mathrm{O}_{2}}$ values of (a) 0.08 and (b) $0.11 \mathrm{~Pa}$ using the hollow $\mathrm{Cu}$ ring above the target (see Fig. 1). The target voltage $\left(\mathrm{V}_{\mathrm{T}}\right)$ and chemical composition from the ERD analysis of the samples at the various deposition conditions are also provided. The vertical lines indicate the peak positions in the reference $\mathrm{HfO}_{2}$ patterns.

than those in Set 1. Despite the changes in the process characteristics, the influence of the $\mathrm{O}_{2}$ partial pressure on the phase formation is identical to Set 1 . Patterns of films deposited in the transition zone $\left[\mathrm{p}_{\mathrm{O}_{2}}=0.08 \mathrm{~Pa}\right.$, Fig. 7(a) $]$ resemble those of the $\mathrm{t}-$ and/or the c- $\mathrm{HfO}_{2}$ crystal structure, while deposition in the oxidic sputtering mode $\left[\mathrm{p}_{\mathrm{O}_{2}}=0.11 \mathrm{~Pa}\right.$, Fig. 7 (b)] results in the formation of $\mathrm{m}-\mathrm{HfO}_{2}{ }^{4{ }^{2}}$ Moreover, the increase in the $\mathrm{O}_{2}$ partial pressure results in an increase in the $\mathrm{O}$ content in the film at the expense of $\mathrm{Hf}$ and $\mathrm{N}$ content as shown in Figs. 7(a) and 7(b).

The HPPMS process without $\mathrm{N}_{2}$ addition (Set 3) exhibited target voltages approximately $50 \mathrm{~V}$ larger than those obtained in the experimental Set 1 . The larger $\mathrm{V}_{\mathrm{T}}$ values are a fingerprint of the HPPMS process. ${ }^{32,33}$ The effect of the $\mathrm{p}_{\mathrm{O}_{2}}$ on the XRD patterns for the deposition Set 3 is demonstrated in Fig. 8. Similarly to Sets 1 and 2, operation in the transition zone results in a pattern with peaks between those of the tand/or the $\mathrm{c}-\mathrm{HfO}_{2}$ structure [Fig. 8(a)]. On the other hand, growth in oxidic mode $\left(\mathrm{p}_{\mathrm{O}_{2}}=0.15 \mathrm{~Pa}\right)$ leads to a diffraction pattern consistent with that of the $\mathrm{m}-\mathrm{HfO}_{2}$ structure [Fig. $8(\mathrm{~b})]$. It is also seen that the diffraction peaks that correspond to the m- $-\mathrm{HfO}_{2}$ crystal structure [Fig. 8(b)] are left shifted

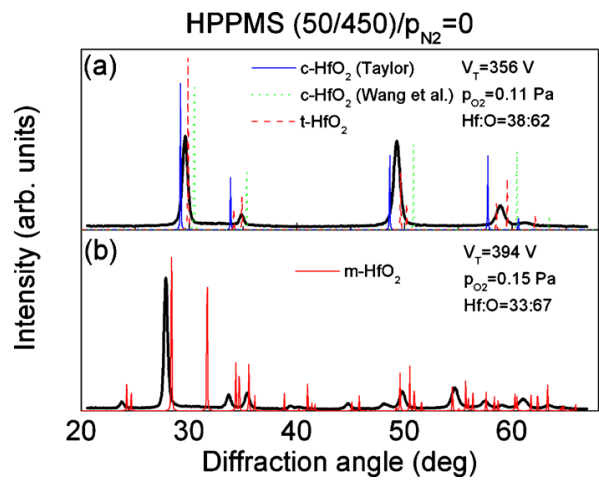

FIG. 8. (Color online) X-ray diffraction patterns of samples deposited by HPPMS (pulse on-time and off-time 50 and $450 \mu$ s, respectively) in an Ar $-\mathrm{O}_{2}$ at $\mathrm{p}_{\mathrm{O}_{2}}$ values of (a) 0.11 and (b) $0.15 \mathrm{~Pa}$. The target voltage $\left(\mathrm{V}_{\mathrm{T}}\right)$ and chemical composition from the ERD analysis of the samples at the various deposition conditions are also provided. The vertical lines indicate the peak positions in the reference $\mathrm{HfO}_{2}$ patterns. 
TABLE I. Equilibrium lattice parameters for $\mathrm{c}-, \mathrm{t}-$, and $\mathrm{m}-\mathrm{HfO}_{2}$ calculated by DFT in the current study. The lattice parameters calculated by Zhao and Vanderbilt, (Ref. 2) as well as experimentally determined (Refs. 46, 47, 50, and 51) lattice parameters are also provided for reference.

\begin{tabular}{lccc}
\hline \hline & Present work & Zhao and Vanderbilt & \\
\hline c- ${ }^{\mathrm{a}} \mathrm{Exp}_{2}$ & & & \\
$\mathrm{a}(\AA)$ & 5.056 & & $5.08-5.295$ \\
$\mathrm{t}-\mathrm{HfO}{ }_{2}$ & & 5.298 & \\
$\mathrm{a}(\AA)$ & 5.060 & 5.373 & 5.14 \\
$\mathrm{c}(\AA)$ & 5.243 & & 5.25 \\
$\mathrm{~m}-\mathrm{HfO}{ }_{2}$ & & 5.291 & \\
$\mathrm{a}(\AA)$ & 5.272 & 5.405 & 5.117 \\
$\mathrm{~b}(\AA)$ & 5.102 & 5.366 & 5.175 \\
$\mathrm{c}(\AA)$ & 5.246 & 97.72 & 5.291 \\
$\beta\left({ }^{\circ}\right)$ & 96.29 & & 99.22 \\
\hline \hline
\end{tabular}

${ }^{2}$ Reference 2 .

${ }^{b}$ c- $-\mathrm{HfO}_{2}$ (Refs. 46 and 47), t- $\mathrm{HfO}_{2}$ (Ref. 50), m-HfO ${ }_{2}$ (Ref. 51).

with respect to the reference $\mathrm{m}-\mathrm{HfO}_{2}$ peaks by $\sim 0.6^{\circ}$. The corresponding shift for the deposition Sets 1 and 2 is $\sim 0.2^{\circ}$. The larger left shift in the diffraction peaks for the HPPMS grown samples may be correlated with the more intense energetic bombardment in HPPMS as compared to dcMS (Refs. 32 and 33) and the subsequent larger lattice expansion. Moreover, chemical composition measurements showed that deposition in the transition zone [Fig. 8(a)] results in films with $\mathrm{O}$ content 5 at. \% smaller than that of the nominal stoichiometry [Fig. 8(b)]. The growth of $\mathrm{O}$ deficient films (i.e., formation of $\mathrm{O}$ vacancies) when films are deposited in the transition zone is a fingerprint of reactive sputtering. 25

\section{DFT calculations}

The equilibrium lattice parameters calculated for the stoichiometric c-, t-, and $\mathrm{m}-\mathrm{Hf}_{16} \mathrm{O}_{32}$ cells are listed in Table I. The lattice parameters calculated by Zhao and Vanderbilt ${ }^{2}$ implementing ultrasoft pseudopotentials, as well as experimentally determined ${ }^{48,49,52,53}$ lattice parameters obtained from $\mathrm{x}$-ray diffraction of powders are also provided for reference. It is seen that our results are in agreement with the experiment within an accuracy of $\sim 2.5 \%$. The effect of the $\mathrm{O}$ vacancy formation and the $\mathrm{N}$ incorporation on the energetics of the $\mathrm{Hf}_{16} \mathrm{O}_{32-x}$ and the $\mathrm{Hf}_{16} \mathrm{O}_{32-x} \mathrm{~N}_{x}$ cells is demon-

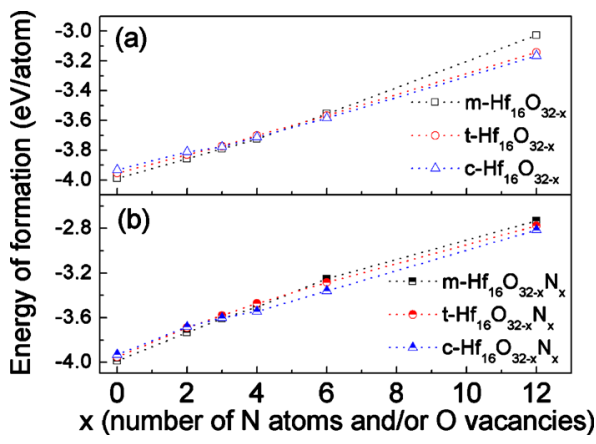

FIG. 9. (Color online) Energy of formation of (a) $\mathrm{Hf}_{16} \mathrm{O}_{32-x}$ and (b) $\mathrm{Hf}_{16} \mathrm{O}_{32-x} \mathrm{~N}_{x}$ cell with the crystal structure of $\mathrm{m}$ - (square), t- (circle) and c- $\mathrm{HfO}_{2}$ (triangle) for $x$ values ranging from 0 to 12 .

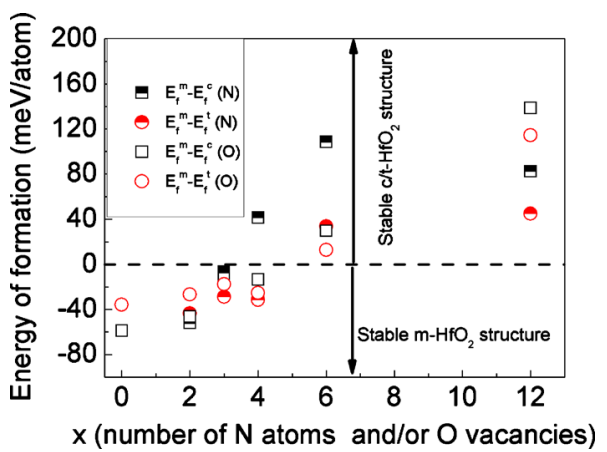

FIG. 10. (Color online) Differences of the energy of formation for tetragonal and cubic $\mathrm{Hf}_{16} \mathrm{O}_{32-x}$ (hollow symbols) and $\mathrm{Hf}_{16} \mathrm{O}_{32-x} \mathrm{~N}_{x}$ (half filled symbols) cells ( $E_{f}^{c}$ and $E_{f}^{t}$, respectively) from the energy of formation of the corresponding monoclinic cells $\left(E_{f}^{m}\right)$ for $x$ values ranging from 0 to 12 .

strated in Figs. 9(a) and 9(b), respectively. An increase in $x$ (number of $\mathrm{O}$ vacancies and $\mathrm{N}$ atoms in the cell) from 0 to 12 results in an increase in the $E_{f}$ of all crystal structures in the order of $\sim 1.0 \mathrm{eV} /$ atom. Moreover, the presence of $\mathrm{O}$ vacancies and $\mathrm{N}$ atoms in the cell affects the order of the energy of formation of the various phases. This is also demonstrated in Fig. 10 where the differences of the energy of formation for tetragonal and cubic $\mathrm{Hf}_{16} \mathrm{O}_{32-x}$ (hollow symbols) and $\mathrm{Hf}_{16} \mathrm{O}_{32-x} \mathrm{~N}_{x}$ (half filled symbols) cells ( $E_{f}^{c}$ and $E_{f}^{t}$, respectively) from the energy of formation of the corresponding monoclinic cells $\left(E_{f}^{m}\right)$ is plotted. When no $\mathrm{O}$ vacancies or $\mathrm{N}$ atoms are present, $E_{f}^{m}-E_{f}^{t}$ and $E_{f}^{m}-E_{f}^{c}$ values of $-35 \mathrm{meV} /$ atom and $-58 \mathrm{meV} / \mathrm{atom}$ are, respectively, obtained, i.e., the energy of formation of the monoclinic cell is smaller than those of the cubic and the tetragonal cells. An increase in the $\mathrm{O}$ vacancy of $\mathrm{N}$ atom concentration results in an increase in the absolute values of the energy differences which become positive for $x=6$.

\section{DISCUSSION}

The position and the shift in the onset of the high-energy $\mathrm{O}^{-}$populations in Figs. 2 and 4 are consistent with the corresponding $\mathrm{V}_{\mathrm{T}}$ values which are also provided there. This is in agreement with previous observations by Mráz and Schneider ${ }^{27,28}$ and indicates that these species are generated on the surface of the oxidized target and accelerated across the sheath by the negative target potential toward the growing film. ${ }^{27,28}$ Therefore, their energy is largely determined by the value of the target voltage. The fact that the intensity of the IEDFs presented in Fig. 2 increases when the $\mathrm{O}_{2}$ partial pressure is increased signifies an increase in the flux of $\mathrm{O}^{-}$ species toward the growing film upon moving from a nonoxidized to an oxidized target. This, in turn, confirms the suggestion by Severin et al., ${ }^{22}$ i.e., the operation in the transition zone allows for a suppression of the $\mathrm{O}^{-}$bombardment as compared to the operation in the oxidic sputtering mode. It is, therefore, evident that our experimental strategy that enables operation at different target working points (via the stabilization of the transition zone and variation in the $\mathrm{O}_{2}$ partial pressure) and target voltages (via the implementation of HPPMS) facilitates growth of films at different conditions of energetic bombardment with respect to the flux the energy of the $\mathrm{O}^{-}$species. Furthermore, the implementation of the $\mathrm{Cu}$ 
ring above the target surface allows for film growth without bombardment by high-energy $\mathrm{O}^{-}$species, as shown in Fig. 3. This is an experimental validation of previous proposals ${ }^{30,54}$ that $\mathrm{O}^{-}$ions generated at the target surface are accelerated perpendicularly to the erosion track and can be, therefore, blocked en route to the substrate when a ring of a proper geometry is placed above the target (see Fig. 1). The results presented in Figs. 5, 7, and 8 show that the crystal structure of the deposited films changes from the c- and/or $\mathrm{t}-\mathrm{HfO}_{2}$ to that of the $\mathrm{m}-\mathrm{HfO}_{2}$ upon moving across the transition zone toward the oxidic sputtering mode. The fact that the transition from the $\mathrm{c} / \mathrm{t}$ - to the $\mathrm{m}-\mathrm{HfO}_{2}$ crystal structure is observed irrespective of the $\mathrm{O}^{-}$bombardment conditions employed for the growth unambiguously proves that $\mathrm{O}^{-}$ions with energies of several hundreds of electron volt typically encountered in magnetron sputtering processes do not determine the phase formation in reactively sputtered HfON films. This is consistent with previous observations by Miyake et al. ${ }^{55}$ who reported that $\mathrm{O}$ ion energies of several kilo electron volt are required to affect the phase formation in ion beam assisted deposited $\mathrm{HfO}_{2}$ films. As a consequence, previously published experimental reports ${ }^{22}$ which postulated that the $\mathrm{O}^{-}$ ion bombardment is decisive for the phase in reactively sputtered zirconium oxynitride films should be re-evaluated.

It is, therefore, evident from the discussion presented above that a different mechanism determines the phase formation data reported in hafnium oxynitride films. It is seen in Figs. 5, 7, and 8 that the growth of films with $\mathrm{c} / \mathrm{t}-\mathrm{HfO}_{2}$ crystal structure is accompanied by the formation of $\mathrm{O}$ vacancies and/or by $\mathrm{N}$ incorporation in the film. The binding energy of $395.9 \mathrm{eV}$ for the $\mathrm{N} 1 s$ peak in Fig. 6(b) lies well below the to $\mathrm{N}-\mathrm{N}$ (which would correspond to $\mathrm{N}_{2}$ formation) or $\mathrm{N}-\mathrm{O}$ (which would correspond to the formation of $\mathrm{NO}$ or $\mathrm{NO}_{2}$ ) bonds ${ }^{49,14,56,57}$ and can, therefore, be attributed to Hf-N bonds. ${ }^{14,56,57}$ Thus, $\mathrm{N}$ atoms in the hafnium oxynitride crystal occupy $\mathrm{O}$ sublattice sites, ${ }^{14,56,57}$ which is the configuration described in our DFT calculations (see Sec. III). The results of these calculations (Figs. 9 and 10) show that in the stoichiometric $\mathrm{Hf}_{16} \mathrm{O}_{32}$ configuration the monoclinic phase exhibits with $-3.989 \mathrm{eV} /$ atom the lowest energy of formation and is, therefore, more stable than the tetragonal and the cubic phases with respective energies of formation of -3.954 and $-3.931 \mathrm{eV} /$ atom. The presence of $\mathrm{O}$ vacancies and the substitution of $\mathrm{O}$ by $\mathrm{N}$ atoms cause these energy differences to become smaller and for $x=6$ the energies of formation of the cubic and the tetragonal $\mathrm{Hf}_{16} \mathrm{O}_{32-x}$ and $\mathrm{Hf}_{16} \mathrm{O}_{32-x} \mathrm{~N}_{x}$ cells become lower in comparison to that of the monoclinic cells. These results indicate that the formation of $\mathrm{O}$ vacancies and/or the substitution of $\mathrm{O}$ by $\mathrm{N}$ atoms energetically favor the c- and $\mathrm{t}-\mathrm{HfO}_{2}$ crystal structures at the expense of the $\mathrm{m}-\mathrm{HfO}_{2}$ and signify the decisive role of the nonmetal sublattice configuration for the phase formation of reactively sputtered $\mathrm{HfON}$ films.

\section{CONCLUSIONS}

In the current study, dcMS in an $\mathrm{Ar}-\mathrm{O}_{2}-\mathrm{N}_{2}$ atmosphere and HPPMS in an $\mathrm{Ar}-\mathrm{O}_{2-}$ atmosphere were employed to deposit hafnium oxynitride and oxide films, respectively. The presence of $\mathrm{N}_{2}$ in the sputtering atmosphere, as well as the implementation of HPPMS enabled the stabilization of the transition zone between the metallic and the oxidic sputtering zone, as well as operation at different values of target voltage. Variation in the $\mathrm{O}_{2}$ partial pressure allowed for deposition of films at well defined target coverage conditions in the metallic, the transition and the oxidic zone. Plasma analysis showed that this experimental strategy enabled control over the energy and the flux of $\mathrm{O}^{-}$ions which are generated at the oxidized target surface and accelerated by the negative target potential toward the growing film. An experimental arrangement that facilitated the suppression of the $\mathrm{O}^{-}$ ion bombardment during the film growth was also implemented. Structural characterization of the films revealed that, irrespective of the $\mathrm{O}^{-}$ion bombardment conditions, deposition in the oxidic sputtering mode led to the growth of films with the crystal structure of the $\mathrm{m}-\mathrm{HfO}_{2}$, while films deposited in the transition zone exhibit the crystal structure of cand/or t- $\mathrm{HfO}_{2}$. Analysis of the chemical composition showed that the formation of the $\mathrm{c} / \mathrm{t}-\mathrm{HfO}_{2}$ crystal structure is accompanied by the formation of $\mathrm{O}$ vacancies and substitution of $\mathrm{O}$ by $\mathrm{N}$ atoms in the nonmetal sublattice. $A b$ initio calculations within DFT revealed that $\mathrm{O}$ vacancies and/or $\mathrm{N}$ incorporation energetically favor the formation of the $\mathrm{c} / \mathrm{t}-\mathrm{HfO}_{2}$ phases at the expense of the $\mathrm{m}-\mathrm{HfO}_{2}$ one. It is, therefore, evident that the phase formation in reactively sputtered hafnium oxide and oxynitride films is not determined by the $\mathrm{O}^{-}$bombardment but rather by the nonmetal sublattice configuration.

\section{ACKNOWLEDGMENTS}

This work has been financed by the German Research Foundation (Deutsche Forschungsgemeinschaft) within the project Sch./14-2. One of the authors (S. Konstantinidis) acknowledges the Belgian Foundation for Scientific Research (FNRS) for the financial support.

${ }^{1}$ B. Predel, $H f-O$, Landolt-Börnstein, New Series Vol. IV/5f (SpringerVerlag, Berlin, 1996).

${ }^{2}$ H. Wang, Y. Wang, J. Zhang, C. Ye, H. B. Wang, J. Weng, B. Y. Wang, Q. Li, and Y. Jiang, Appl. Phys. Lett. 93, 202904 (2008).

${ }^{3}$ H. Wang, Y. Wang, J. Feng, C. Ye, B. Y. Wang, H. B. Wang, Q. Li, Y. Jiang, A. P. Huang, and Z. S. Xiao, Appl. Phys. A: Mater. Sci. Process. 93, 681 (2008).

${ }^{4}$ X. Zhao and D. Vanderbilt, Phys. Rev. B 65, 233106 (2002).

${ }^{5}$ G. D. Wilk, R. M. Wallace, and J. M. Anthony, J. Appl. Phys. 89, 5243 (2001).

${ }^{6}$ T. S. Böscke, S. Govindarajan, P. D. Kirsch, P. Y. Hung, C. Krug, B. H. Lee, J. Heitmann, U. Schröder, G. Pant, B. E. Gnade, and W. H. Krautschneider, Appl. Phys. Lett. 91, 072902 (2007).

${ }^{7}$ K. Cherkaoui, S. Monaghan, M. A. Negara, M. Modreanu, P. K. Hurley, D. O'Connell, S. McDonnell, G. Hughes, S. Wright, R. C. Barklie, P. Bailey, and T. C. Q. Noakes, J. Appl. Phys. 104, 064113 (2008).

${ }^{8}$ L. Feng, Z. Liu, and Y. Shen, Vacuum 83, 902 (2009).

${ }^{9}$ C. T. Kuo, R. Kwor, and K. M. Jones, Thin Solid Films 213, 257 (1992).

${ }^{10}$ K. Kita, K. Kyuno, and A. Toriumi, Appl. Phys. Lett. 86, 102906 (2005).

${ }^{11}$ P. Liu, C. Tsai, and P. Yang, Appl. Phys. Lett. 90, 223101 (2007).

${ }^{12}$ L. Pereira, A. Marques, H. Águas, N. Nedev, S. Georgiev, E. Fortunato, and R. Martins, Mater. Sci. Eng., B 109, 89 (2004).

${ }^{13}$ Z. He, W. Wu, H. Xu, J. Zhang, and Y. Tang, Vacuum 81, 211 (2006)

${ }^{14}$ S. J. Wang, J. W. Chai, Y. F. Dong, Y. P. Feng, N. Sutanto, J. S. Pan, and A. C. H. Huan, Appl. Phys. Lett. 88, 192103 (2006).

${ }^{15}$ S. W. Nam, J. Yoo, S. Nam, H. Choi, D. Lee, D. Ko, J. Moon, J. Ku, and S. Choi, J. Non-Cryst. Solids 303, 139 (2002).

${ }^{16}$ W. D. Sproul, M. E. Graham, M. S. Wong, and P. J. Rudnik, Surf. Coat. 
Technol. 89, 10 (1997)

${ }^{17}$ M. Toledano-Luque, E. San Andrés, A. del Prado, I. Mártil, M. L. Lucía, G. González-Díaz, F. L. Martínez, W. Bohne, J. Röhrich, and E. Strub, J. Appl. Phys. 102, 044106 (2007).

${ }^{18}$ E. Hildebrandt, J. Kurian, J. Zimmermann, A. Fleissner, H. von Seggern, and L. Alff, J. Vac. Sci. Technol. B 27, 325 (2009).

${ }^{19}$ E. Rauwel, C. Dubourdieu, B. Holländer, N. Rochat, F. Ducroquet, M. D. Rossell, G. Van Tendeloo, and B. Pelissier, Appl. Phys. Lett. 89, 012902 (2006).

${ }^{20}$ K. Tomida, K. Kita, and A. Toriumi, Appl. Phys. Lett. 89, 142902 (2006).

${ }^{21}$ E. V. Stefanovich, A. L. Shluger, and C. R. A. Catlow, Phys. Rev. B 49 11560 (1994)

${ }^{22}$ D. Severin, K. Sarakinos, O. Kappertz, A. Pflug, and M. Wuttig, J. Appl. Phys. 103, 083306 (2008).

${ }^{23}$ International Centre for Diffraction Data 1999 JCPDS Powder Diffraction File No. 81-1550

${ }^{24}$ D. Severin, O. Kappertz, T. Kubart, T. Nyberg, S. Berg, A. Pflug, M. Simers, and M. Wuttig, Appl. Phys. Lett. 88, 161504 (2006)

${ }^{25}$ S. Berg and T. Nyberg, Thin Solid Films 476, 215 (2005).

${ }^{26} \mathrm{~K}$. Tominaga, D. Ito, and M. Miyamoto, Vacuum 80, 654 (2006).

${ }^{27}$ S. Mráz and J. M. Schneider, J. Appl. Phys. 100, 023503 (2006).

${ }^{28}$ S. Mráz and J. M. Schneider, Appl. Phys. Lett. 89, 051502 (2006).

${ }^{29}$ J. M. Ngaruiya, O. Kappertz, S. H. Mohamed, and M. Wuttig, Appl. Phys. Lett. 85, 748 (2004).

${ }^{30} \mathrm{D}$. Severin, "Strukturbildung und Prozessstabilisierung beim reaktiven Sputtern," Ph.D. thesis, RWTH Aachen University, 2006.

${ }^{31}$ V. Kouznetsov, K. Macák, J. M. Schneider, U. Helmersson, and I. Petrov, Surf. Coat. Technol. 122, 290 (1999).

${ }^{32}$ U. Helmersson, M. Lattemann, J. Bohlmark, A. P. Ehiasarian, and J. T. Gudmundsson, Thin Solid Films 513, 1 (2006).

${ }^{33}$ K. Sarakinos, J. Alami, and S. Konstantinidis, Surf. Coat. Technol. 204 1661 (2010).

${ }^{34}$ E. Wallin and U. Helmersson, Thin Solid Films 516, 6398 (2008).

${ }^{35}$ K. Sarakinos, J. Alami, C. Klever, and M. Wuttig, Surf. Coat. Technol. 202, 5033 (2008).
${ }^{36}$ MELEC GmbH, U.S. Patent No. US 6,735,099 B2 (17 April 2001).

${ }^{37}$ J. Alami, K. Sarakinos, G. Mark, and M. Wuttig, Appl. Phys. Lett. 89, 154104 (2006).

${ }^{38}$ P. Hohenberg and W. Kohn, Phys. Rev. 136, B864 (1964).

${ }^{39}$ G. Kresse and J. Hafner, Phys. Rev. B 48, 13115 (1993).

${ }^{40}$ G. Kresse and J. Hafner, Phys. Rev. B 49, 14251 (1994).

${ }^{41}$ H. J. Monkhorst and J. D. Pack, Phys. Rev. B 13, 5188 (1976).

${ }^{42}$ P. E. Blöchl, Phys. Rev. B 50, 17953 (1994).

${ }^{43}$ A. Zunger, S. H. Wei, L. G. Ferreira, and J. E. Bernard, Phys. Rev. Lett. 65, 353 (1990)

${ }^{44}$ J. M. Cowley, J. Appl. Phys. 21, 24 (1950).

${ }^{45}$ I. A. Abrikosov, A. M. N. Niklasson, S. I. Simak, B. Johansson, A. V. Ruban, and H. L. Skriver, Phys. Rev. Lett. 76, 4203 (1996).

${ }^{46}$ I. A. Abrikosov, S. I. Simak, B. Johansson, A. V. Ruban, and H. L. Skriver, Phys. Rev. B 56, 9319 (1997).

${ }^{47}$ International Centre for Diffraction Data 1999 JCPDS Powder Diffraction File No. 8-342.

${ }^{48}$ D. Taylor, Br. Ceram. Trans. J. 83, 32 (1984).

${ }^{49}$ J. Wang, X. Zheng, and R. Stevens, J. Mater. Sci. 27, 4348 (1992).

${ }^{50}$ International Centre for Diffraction Data 1999 JCPDS Powder Diffraction File No. 34-104.

${ }^{51}$ J. F. Moulder, W. F. Stickle, P. E. Sobol, and K. D. Bomben, Handbook of X-ray Photoelectron Spectroscopy (Perkin-Elmer, Eden Prairie, 1992).

${ }^{52}$ C. E. Curtis, L. M. Doney, and J. R. Johnson, J. Am. Ceram. Soc. 37, 458 (1954).

${ }^{53}$ J. Adam and M. D. Rogers, Acta Crystallogr. 12, 951 (1959).

${ }^{54}$ D. Severin, O. Kappertz, T. Nyberg, S. Berg, and M. Wuttig, Thin Solid Films 515, 3554 (2007)

${ }^{55}$ S. Miyake, I. Shimizu, R. R. Manory, T. Mori, and G. Kimmel, Surf. Coat. Technol. 146-147, 237 (2001).

${ }^{56}$ Y. Wang, H. Wang, J. Zhang, H. Wang, C. Ye, Y. Yiang, and Q. Wang, Appl. Phys. Lett. 95, 032905 (2009).

${ }^{57}$ Y. Chen, Y. P. Feng, J. W. Chai, Z. Zhang, J. S. Pan, and S. J. Wang, Appl. Phys. Lett. 93, 052104 (2008). 